\title{
List of Luhmann's works
}

The following list includes all the books published by Niklas Luhmann, all the works translated into English (in the first section, until 2020) and the articles in German which we refer to at the end of each entry. References at the end of each entry always indicate English translations, when they exist, and in square brackets the year of the first publication.

A complete list of Luhmann's works can be found on the Luhmann-Archiv website: http:/www.uni-bielefeld.de/soz/luhmann-archiv/

\section{English publications and translations}

(1973). Society. In Kernig, C. D. (Ed.), Marxism, Communism and Western Society. A Comparative Encyclopedia, vol. VIII (22-29). New York: Herder \& Herder [(1968). Gesellschaft. In Kernig, C.D. (Ed.), Sowjetsystem und demokratische Gesellschaft. Eine Enzyklopädie (959-972). Freiburg/Basel/Wien: Herder].

(1974). Institutionalized Religion in the Perspective of Functional Sociology. Concilium, 1, 45-55 [(1974). Institutionalisierte Religion gemäß funktionaler Soziologie. Concilium, 10, 17-22].

(1976). A General Theory of Organized Social Systems. In Hofstede, G., \& Kassem, M. S. (Ed.), European Contributions to Organization Theory (96113). Assen: Van Gorcum [(1975). Allgemeine Theorie organisierter Sozialsysteme. In Luhmann, N., Soziologische Aufklärung 2. Aufsätze zur Theorie der Gesellschaft (39-50). Opladen: Westdeutscher Verlag].

(1976). Generalized Media and the Problem of Contingency. In Loubser, J.J., Baum, R.C., Effrat, A., \& Lidz V.M. (Ed.), Explorations in General Theory in Social Science. Essays in Honor of Talcott Parsons, Volume Two, New York/London: Free Press/Collier Macmillan (507-532). 
(1978). Temporalization of Complexity. In Geyer, F., \& van der Zouwen, J., Sociocybernetics. An actor-oriented social systems approach (95-111). Vol. 2. Leiden [(1980). Translation of a shortened version of Temporalisierung von Komplexität: Zur Semantik neuzeitlicher Zeitbegriffe (235300). In Luhmann, N., Gesellschaftsstruktur und Semantik. Vol. I. Frankfurt: Suhrkamp].

(1979). Trust. In Luhmann, N., Trust and Power (1-103). Ed. by Burns, T., \& Poggi, G. Chichester/New York/Brisbane/Toronto: Wiley [(1968). Vertrauen: Ein Mechanismus der Reduktion sozialer Komplexität. Stuttgart: Enke. 2nd extended ed. (1973)].

(1979). Power. In Luhmann, N., Trust and Power (104-208). Ed. by Burns, T., \& Poggi, G. Chichester/New York/Brisbane/Toronto: Wiley [(1975). Macht. Stuttgart: Enke].

(1981). Communication about law in interaction systems. In Knorr-Cetina, K., \& Cicourel, A.V. (Eds.), Advances in social theory and methodology. Toward an integration of micro- and macro-sociologies (234-256). Boston/London/Henley: Routledge \& Kegan Paul [(1980). Kommunikation über Recht in Interaktionssystemen. In Blankenburg, E., Klausa, E., \& Rottleuthner H. (Eds.), Alternative Rechtsformen und Alternativen zum Recht (99-112). Opladen: Westdeutscher Verlag].

(1982). The Differentiation of Society. New York: Columbia UP.

(1982). The Economy as a Social System. In Luhmann, N., The Differentiation of Society (190-225, 386-390) [(1970). Wirtschaft als soziales System. In Luhmann, N., Soziologische Aufklärung (204-231)].

(1983). Insistence on Systems Theory: Perspectives from Germany. An Essay. In Social Forces 61, 987-998.

(1984). Religious Dogmatics and the Evolution of Societies. New York/Toronto: Mellen [(1977). Religiöse Dogmatik und gesellschaftliche Evolution. In Luhmann, N., Funktion der Religion (72-181). Frankfurt: Suhrkamp].

(1984). The Differentiation of Advances in Knowledge. The Genesis of Science.

In Stehr, N., \& Meja V. (Eds.), Society and Knowledge. Contemporary Perspectives in the Sociology of Knowledge (103-148). New Brunswick, N.J./London: Transaction [(1981). Die Ausdifferenzierung von Erkenntnisgewinn. Zur Genese von Wissenschaft. In Stehr, N., \& Meja V. (Eds.), Wissenssoziologie. Kölner Zeitschrift für Soziologie und Sozialpsychologie, Sonderheft, 22, 102-139. Opladen: Westdeutscher Verlag].

(1985). The Work of Art and the Self-Reproduction of Art. In Thesis Eleven 12, 4-27. Reprint (1990). In Luhmann, N., Essays on Self-Reference (191-214) 
[(1984). Das Kunstwerk und die Selbstreproduktion der Kunst. In Delfin 2, 51-69. Reprint (2008). In Luhmann, N., Schriften zu Kunst und Literatur (139-188)].

(1985). A Sociological Theory of Law. London: Routledge [(1972). Rechtssoziologie, 2 vol. Reinbek: Rowohlt. 2nd extended ed. (1983). Opladen: Westdeutscher Verlag].

(1985). The Work of Art and the Self-Reproduction of Art. Thesis Eleven, 12, 4-27. Reprint (2003). In Harrison, C., \& Wood, P. (Ed.), Art in theory 19002000. An anthology of changing ideas (1076-1080). Malden, Ma: Blackwell. Reprint (2009). In Herrero, H, \& Inglis, D. (Eds.), Art and Aesthetics. Art as Social Institution and Collective Practice (191-211). London: Routledge. (1986). Love as Passion. The codification of intimacy. Cambridge: Polity Press [(1982). Liebe als Passion: Zur Codierung von Intimität. Frankfurt: Suhrkamp].

(1986). The Theory of Social Systems and Its Epistemology. Reply to Danilo Zolo's Critical Comments. Philosophy of the social sciences 16, 129-134 [(1983). Risposta dell'autore all'introduzione di Danilo Zolo (Funzione, senso, complessità. Presupposti epistemologici del funzionalismo sistemico). In Schmitt, R. (Ed.), Illuminismo sociologico (XXXV-XLIV). Milano: Il Saggiatore].

(1986). Die Zukunft der Demokratie. In Kiwus, K., \& Binder, K. (Eds.), Der Traum der Vernunft. Vom Elend der Aufklärung. Darmstadt/Neuwied: Luchterhand (207-217). Reprint (1987). In Luhmann, N., Soziologische Aufklärung 4 (126-132). Reprint (2005) (131-138).

(1987). The Evolutionary Differentiation between Society and Interaction. In Alexander, J.C., Giesen, B., Münch, R., \& Smelser, N.J. (Eds.), The MicroMacro Link. Berkeley/Los Angeles/London: University of California Press (112-131).

(1987). Modern Systems Theory and the Theory of Society. In Meja, V., Misgeld, D. \& Stehr, N. (Eds.), Modern German Sociology (173-186). New York: Columbia UP [Moderne Systemtheorie als Form gesamtgesellschaftlicher Analyse. In Adorno, T. W. (Ed.), Spätkapitalismus oder Industriegesellschaft? Verhandlungen des 16. Deutschen Soziologentages vom 8. bis 11. April 1968 in Frankfurt/M. (253-266). Stuttgart: Enke, 1969].

(1988). The Unity of the Legal System. In Teubner, G. (Ed.), Autopoietic Law: A New Approach to Law and Society (12-35). Berlin/New York: de Gruyter [(1983). Die Einheit des Rechtssystems. Rechtstheorie 14, 129-154]. 
(1988). The Sociological Observation of the Theory and Practice of Law. European Yearbook in the Sociology of Law 1, 23-42 [(1985). El enfoque sociólogico de la teoría y práctica del derecho. Anales de la Cátedra Francisco Suárez 25, 87-103].

(1988). Basic Concepts on the Theory of Autopoietic Systems. Nine Questions to Niklas Luhmann and Humberto R. Maturana and Their Answers. In Hargens, J. (Ed.), Systemic Therapy: A European Perspective (79-104). Broadstairs (Kent): Borgmann [(1987). Grundkonzepte der Theorie autopoietischer Systeme. Neun Fragen an Niklas Luhmann und Humberto Maturana und ihre Antworten. Zeitschrift für systemische Therapie, 5, 425].

(1988). The Third Question. The Creative Use of Paradoxes in Law and Legal History. Journal of Law and Society 15, 153-165.

(1988). Tautology and Paradox in the Self-Descriptions of Modern Society. In Sociological Theory 6, 21-37. Reprint (1990). In Luhmann, N., Essays on Self-Reference (123-143) [1987). Tautologie und Paradoxie in den Selbstbeschreibungen der modernen Gesellschaft. In Zeitschrift für Soziologie 16. 161-174. Reprint (1996). In Luhmann, N., Protest (79-106)].

(1988) Familiarity, Confidence, Trust: Problems and Alternatives. In Gambetta, D. (ed.) Trust: Making and Breaking

Cooperative Relations (94-107). Department of Sociology, University of Oxford.

(1989). Ecological Communication. Cambridge, Engl.: Polity Press [(1986). Ökologische Kommunikation: Kann die moderne Gesellschaft sich auf ökologische Gefährdungen einstellen? Opladen: Westdeutscher Verlag].

(1990). Political Theory in the Welfare State. Berlin: de Gruyter (includes also chapters from (1987). Soziologische Aufklärung 4) [(1981). Politische Theorie im Wohlfahrtsstaat. Munich: Olzog].

(1990). Essays on Self-Reference. New York: Columbia UP.

(1991). Paradigm lost: On the Ethical Reflection of Morality. Thesis Eleven, 29, 82-94 [(1990). Paradigm lost: Über die ethische Reflexion der Moral. Frankfurt: Suhrkamp].

(1990). Sthenography. Stanford Literature Review, 7, 133-137 [(1987/88). Sthenographie. Delfin, 5, 4-12].

(1990). The Cognitive Program of Constructivism and a Reality that Remains Unknown. In Krohn, W., Küppers, G., Nowotny, H. (Eds.), Selforganization: Portrait of a Scientific Revolution (64-85). Dordrecht. Reprint (2002). In Luhmann, N., Theories of Distinction: Rediscriptions of the Descrip- 
tions of Modernity (128-152). Ed. by Rasch, W. Stanford UP, Reprint (2003). In Delanty, G., \& Strydom, P. (Eds.), Philosophies of Social Science. The classic and contemporary readings (436-441). Maidenhead/Philadelphia: Open UP [(1990). Das Erkenntnisprogramm des Konstruktivismus und die unbekannt bleibende Realität. In Luhmann, N., Soziologische Aufklärung (31-58). Vol. 5. Westdeutscher Verlag: Opladen].

(1990). Meaning as Sociology's Basic Concept. In Luhmann, N., Essays on SelfReference (21-79). New York: Columbia UP [(1971). Sinn als Grundbegriff der Soziologie. In Luhmann, N., Habermas, J. Theorie der Gesellschaft oder Sozialtechnologie (25-100)].

(1991). Paradigm Lost: On the Ethical Reflection of Morality. Speech on the Occasion of the Award of the Hegel Prize 1989. Thesis eleven, 29, 82-94 [Paradigm lost: Über die ethische Reflexion der Moral. Rede anläßlich der Verleihung des Hegel-Preises 1989. In Luhmann, N., Paradigm lost: Über die ethische Reflexion der Moral (7-48). Frankfurt: Suhrkamp, 1990].

(1991/92). Operational Closure and Structural Coupling. The Differentiation of the Legal System. Cardozo Law Review, 13, 1419-1441. Reprint (2001). In Cotterrell R. (Ed.), Sociological Perspectives on Law: Contemporary Debates (95-117). Vol. 2, Aldershot/Burlington: Ashgate/Dartmouth.

(1992). The Form of Writing. Stanford Literature Review, 9(1), 25-42.

(1992). Societal Complexity. In Széll, G. (Ed.), Concise Encyclopaedia of Participation and Co-Management (793-806). Berlin/New York: de Gruyter [(1992), Complessità sociale. In Enciclopedia delle Scienze Sociali (126-134). Vol. II. Roma: Istituto della Enciclopedia Italiana].

(1992). Perception and Communication through Artworks. In Lux, H., \& Ursprung, P. (Eds.), STILLSTAND switches. Ein Gedankenaustausch zur Gegenwartskunst. An Exchange of Ideas on Contemporary Art. Symposium, Interviews. Shedhalle Zürich, 8.-24.6.1991 (75-84). Zürich: Shedhalle [(1992). Wahrnehmung und Kommunikation an Hand von Kunstwerken. Ibidem (65-74). Reprint (2008). In Luhmann, N., Schriften zu Kunst und Literatur (246-257). Frankfurt: Suhrkamp].

(1992). The Concept of Society. Thesis Eleven, 31, 67-80.

(1992). What is Communication? In Communication Theory, 2, 251-259. Reprint (2002). In Luhmann, N., Theories of Distinction (155-168) [slightly revised translation of (1987). Was ist Kommunikation? In Information Philosophie, 15, 4-16].

(1993). Observing Re-entries. Graduate Faculty Philosophy Journal, 16, 485498. 
(1993). Are There Still Indispensable Norms in Our Society? Soziale Systeme, 14, 18-37 [(1993). Gibt es in unserer Gesellschaft noch unverzichtbare Normen? Heidelberg: C.F. Müller].

(1993). Risk: A Sociological Theory. Berlin: de Gruyter. Reprint (2005). With a new introduction by Stehr,N., \& Bechmann, G. New Brunswick: Aldine Transaction [(1991). Soziologie des Risikos. Berlin: de Gruyter].

(1994). How Can the Mind Participate in Communication? In Gumbrecht, H. U., \& Pfeiffer, K. L. (Eds.), Materialities of Communication (371-387). Stanford UP [(1988). Wie ist Bewußtsein an Kommunikation beteiligt? In Gumbrecht, H. U., \& Pfeiffer, K. L. (Eds.), Materialität der Kommunikation (884-905). Frankfurt: Suhrkamp].

(1994). Speaking and Silence. New German Critique, 61, 25-38 [(1989). Reden und Schweigen. In Luhmann, N., \& Fuchs, P., Reden und Schweigen (720)].

(1994). Politicians, Honesty and the Higher Amorality of Politics. Theory, culture \& society, 11, 25-36 [(1993). Die Ehrlichkeit der Politiker und die höhere Amoralität der Politik. In Kemper, P. (Ed.), Opfer der Macht. Müssen Politiker ehrlich sein? (27-41). Frankfurt/Leipzig: Insel. Reprint (2008). In Luhmann, N., Die Moral der Gesellschaft (163-174). Ed. by Horster, D. Frankfurt: Suhrkamp].

(1995) Social Systems. Stanford UP. [(1984). Soziale Systeme: Grundriß einer allgemeinen Theorie. Frankfurt: Suhrkamp].

(1995). Why 'Systems Theory'? Cybernetics \& human knowing, 3, 3-10 [(1992). Hvorfor „Systemteorie“? In Jacobsen J. C. (Ed.), Autopoiesis. En introduktion til Niklas Luhmanns verden af systemer (10-20, 197-200). Copenhagen: Forlaget Politisk Revy].

(1995). The Two Sociologies and the Theory of Society. Thesis Eleven, 43, 28-47 [(1993). „Was ist der Fall?“ und „Was steckt dahinter?“. Die zwei Soziologien und die Gesellschaftstheorie. Zeitschrift für Soziologie, 22, 245-260].

(1995). The Challenge of Being New. In Salzburger Kunstverein (Ed.), Original. Symposium Salzburger Kunstverein (51-55). Ostfildern: Cantz [(1995). Neu-sein als Herausforderung. Ibidem (45-50)].

(1995). Society, Meaning, Religion-Based on Self-Reference. In Bruce S. (Ed.), The Sociology of Religion (245-260). Vol. 1. Aldershot Hants: Edward Elgar].

(1995). Theory of a Different Order. A Conversation with Katherine Hayles and Niklas Luhmann. In Knodt, E., Rasch W., \& Wolfe, C. (Eds.), The Politics of Systems and Environments (7-36). Part II, Minneapolis: Univer- 
sity of Minnesota Press. Reprint (2000). In Rasch, W. (Ed.), Niklas Luhmann's Modernity. The Paradoxes of Differentiation (171-194). Stanford UP. Reprint (2000). In Rasch, W., \& Wolfe, C. (Eds.), Observing Complexity. Systems Theory and Postmodernity (111-136). Minneapolis: University of Minnesota Press.

(1995). Why Does Society Describe Itself as Postmodern? Cultural Critique, 30, 171-186. Reprint (2000). In Rasch, W. \& Wolfe, C. (Eds.), Observing Complexity. Systems Theory and Postmodernity (35-50). Minneapolis: University of Minnesota Press.

(1995). The Paradox of Observing Systems. In Cultural Critique 31, 37-55.

Reprint (2002). In Luhmann, N., Theories of Distinction (79-93).

(1995). Interview with Professor Niklas Luhmann, Oslo April, 2. Cybernetics

\& Human Knowing, 3, 23-26.

(1996). Complexity, Structural Contingencies and Value Conflicts. In Heelas,

P., Lash, S., \& Morris, P. (Eds.), Detraditionalization. Critical Reflections on Authority and Identity (59-71). Cambridge/Oxford: Blackwell.

(1996). The Sociology of the Moral and Ethics. International Sociology, 11, 2736.

(1996). On the Scientific Context of the Concept of Communication. Social Science Information, 35, 257-267.

(1996). A Redescription of „Romantic Art“. MLN, 111, 506-522 [(1996). Eine Redeskription „romantischer Kunst“. In Fohrmann, J., \& Müller H. (Eds.), Systemtheorie der Literatur (325-344). Munich: Fink. Reprint (2008). In Luhmann, N., Schriften zu Kunst und Literatur (353-372). Frankfurt: Suhrkamp].

(1996). Quod omnes tangit. Remarks on Jürgen Habermas's Legal Theory. Cardozo Law Review, 17, 883-899. Reprint (1998). In Rosenfeld, M., \& Arato, A. (Eds.), Habermas on Law and Democracy. Critical Exchanges (157-172). Berkeley, Cal./Los Angeles/London: University of California Press [(1993). Quod omnes tangit. Anmerkungen zur Rechtstheorie von Jürgen Habermas. Aus Anlaß von Jürgen Habermas, Faktizität und Geltung: Beiträge zur Diskurstheorie des Rechts und des demokratischen Rechtsstaats, Frankfurt a. M.: Suhrkamp 1992. Rechtshistorisches Journal, 12, 36-56].

(1996). Modern Society Shocked by its Risks. Department of Sociology, The University of Hongkong, Occasional Papers 17. Hongkong.

(1997). Limits of Steering. Theory, culture \& society, 4, 41-57 [(1988). Grenzen der Steuerung. In Luhmann, N., Die Wirtschaft der Gesellschaft (324-349). Frankfurt: Suhrkamp]. 
(1997). The Control of Intransparency. Systems Research and Behavioral Science, 14, 359-371 [(1997). Die Kontrolle von Intransparenz. in: Ahlemeyer, H. W., \& Königswieser, R. (Eds.), Komplexität managen. Strategien, Konzepte und Fallbeispiele (51-76). Frankfurt/Wiesbaden: Frankfurter Allgemeine Zeitung/Gabler].

(1997). Globalization or World Society. How to Conceive of Modern Society? International Review of Sociology, 7, 67-79.

(1998). Politics and Economy. Thesis Eleven, 53, 1-9.

(1998). Observations on Modernity. Stanford UP [(1992). Beobachtungen der Moderne. Opladen: Westdeutscher Verlag].

(1998). Modernity in Contemporary Society. In Luhmann, N., Observations on Modernity (1-21).

(1998). European Rationality. In Luhmann, N., Observations on Modernity (22-43).

(1999). The Concept of Society. In Elliott, A. (Ed.), The Blackwell Reader in Contemporary Social Theory (143-155). London: Blackwell [(1991). Pojem družbe. In Teorija in praksa, 28, 1175-1185].

(1999). The Paradox of Form. In Baecker, D. (Ed.), Problems of Form (15-26). Stanford UP [(1993). Die Paradoxie der Form. In Baecker, D. (Ed.), Probleme der Form (197-212). Frankfurt: Suhrkamp].

(1999). Sign as Form. In Baecker, D. (Ed.), Problems of Form (46-63). Stanford UP [(1993). Zeichen als Form. In Baecker D. (Ed.), Probleme der Form (4569). Frankfurt: Suhrkamp].

(2000). Problems of Reflection in the System of Education. Münster/New York: Waxmann [(1979). Reflexionsprobleme im Erziehungssystem. Stuttgart: Klett-Cotta (together with Karl Eberhard Schorr). Reprint (1988). With a „Nachwort 1988“, Frankfurt: Suhrkamp].

(2000). Art as a Social System. Stanford UP [(1995). Die Kunst der Gesellschaft. Frankfurt: Suhrkamp].

(2000). The Reality of the Mass Media. Stanford UP [(1996). Die Realität der Massenmedien. Opladen: Westdeutscher Verlag].

(2001). Notes on the Project "Poetry and Social Theory". Theory, Culture \& Society, 18, 15-27 [(1999). Notizen zum Projekt „Lyrik und Gesellschaftstheorie“. Soziale Systeme, 5, 214-237].

(2002). Husserl, Science, Modernity, in Theories of Distinction: Rediscriptions of the Descriptions of Modernity (33-60) [(1996). Die neuzeitlichen Wissenschaften und die Phänomenologie. Wien: Picus]. 
(2002). Theories of Distinction: Rediscriptions of the Descriptions of Modernity. Ed. by Rasch, W. Stanford UP.

(2002). Identity-What or How? In Luhmann, N., Theories of Distinction (113-127) [(1990). Identität-was oder wie? In Luhmann, N., Soziologische Aufklärung 5 (14-30)].

(2003). Organization. In Bakken, T., \& Hernes, T. (Eds.), Autopoietic Organization Theory. Drawing on Niklas Luhmann's Social Systems Perspective (31-52). Herndon/Malmö/Oslo: Copenhagen Business School Press/Liber/Abstrakt [(1988). Organisation. In Küpper, W., \& Ortmann, G. (Eds.), Mikropolitik. Rationalität, Macht und Spiele in Organisationen (165-185). Opladen: Westdeutscher Verlag].

(2004) Law as a Social System. Oxford/New York: Oxford UP [(1993). Das Recht der Gesellschaft. Frankfurt: Suhrkamp].

(2006). Communication Barriers in Management Consulting. In Seidl, D., \& Becker, K. H. (Eds.), Niklas Luhmann and Organization Studies (351-364). Malmö: Liber \& CBS Press [(1989). Kommunikationssperren in der Unternehmensberatung. In Luhmann, N., \& Fuchs, P., Reden und Schweigen (209-227)].

(2006). The Paradox of Decision Making. In Seidl, D., \& Becker, K. H. (Eds.), Niklas Luhmann and Organization Studies (85-106). Malmö: Liber \& CBS Press [(1993). Die Paradoxie des Entscheidens. Verwaltungsarchiv, 84, 287310].

(2006). The Autopoiesis of Social Systems. In Seidl, D., \& Becker, K. H. (Eds.),

Niklas Luhmann and Organization Studies (64-84). Malmö: Liber \& CBS Press.

(2006). The Concept of Autopoiesis. In Seidl, D., \& Becker, K. H. (Eds.), Niklas Luhmann and Organization Studies (54-63). Malmö: Liber \& CBS Press [(2000). Translation of the chapter Organisation als autopoietisches System. In Luhmann, N., Organisation und Entscheidung (44-55). Westdeutscher Verlag: Opladen].

(2008). Are There Still Indispensable Norms in Our Society? Soziale Systeme,

14, 18-37 [(1993). Gibt es in unserer Gesellschaft noch unverzichtbare Normen? Heidelberg: C. F. Müller].

(2008). Beyond Barbarism. Soziale Systeme, 14, 38-46 [(1995). Jenseits von Barbarei. In Luhmann, N., Gesellschaftsstruktur und Semantik. Studien zur Wissenssoziologie der modernen Gesellschaft (138-150). Vol. 4. Frankfurt: Suhrkamp). 
(2010). Love. A sketch. London: Polity Press [(2008). Liebe. Eine Übung. Ed. by Kieserling, A. Frankfurt: Suhrkamp].

(2012). Introduction to Systems Theory. Cambridge: Polity Press [(2002). Einführung in die Systemtheorie. Ed. by Baecker, D. Heidelberg: Carl-AuerSysteme Verlag].

(2012/2013). Theory of Society. Vol. 1 and vol. 2. Stanford UP [(1997). Die Gesellschaft der Gesellschaft, 2 vol. Frankfurt: Suhrkamp].

(2013). A Systems Theory of Religion. Stanford UP [(2000). Die Religion der

Gesellschaft. Ed. by Kieserling, A. Frankfurt: Suhrkamp].

(2018). The New Boss. Cambridge: Polity [(2016). Der neue Chef. Berlin: Suhrkamp]

(2018). Organization and Decision, Cambridge/New York: Cambridge UP [(2000). Organisation und Entscheidung. Ed. by Baecker, D. Opladen: Westdeutscher Verlag]

\section{Publications in German (books and cited references)}

(1963). Verwaltungsfehler und Vertrauensschutz: Möglichkeiten gesetzlicher Regelung der Rücknehmbarkeit von Verwaltungsakten. Berlin: Duncker $\&$ Humblot (together with Franz Becker).

(1964). Funktionen und Folgen formaler Organisation. Berlin: Duncker \& Humblot. 4th ed. (1995). With an "Epilog 1994".

(1964) Funktionale Methode und Systemtheorie. In Soziale Welt 15, 1-25. Reprint (1970). In Luhmann, N., Soziologische Aufklärung (31-53).

(1965). Öffentlich-rechtliche Entschädigung rechtspolitisch betrachtet. Berlin:

Duncker \& Humblot.

(1965). Grundrechte als Institution: Ein Beitrag zur politischen Soziologie.

Berlin: Duncker \& Humblot.

(1966). Recht und Automation in der öffentlichen Verwaltung: Eine verwaltungswissenschaftliche Untersuchung. Berlin: Duncker \& Humblot.

(1966). Theorie der Verwaltungswissenschaft: Bestandsaufnahme und Entwurf. Cologne/Berlin.

(1966). Automation in der öffentlichen Verwaltung. Hamburg: Verlag Deutsche Polizei (together with Wilhelm Wortmann). 
(1967) Soziologische Aufklärung. In Soziale Welt 18, 97-123. Reprint (1970). In Luhmann, N., Soziologische Aufklärung (66-91). Reprint (2005). Wiesbaden: VS Verlag für Sozialwissenschaften (83-115).

(1968). Zweckbegriff und Systemrationalität: Über die Funktion von Zwecken in sozialen Systemen. Tübingen: J.C.B. Mohr, Paul Siebeck. Reprint (1973). Frankfurt: Suhrkamp.

(1969). Legitimation durch Verfahren. Neuwied/Berlin: Luchterhand. Reprint (1983). Frankfurt: Suhrkamp.

(1970). Soziologische Aufklärung: Aufsätze zur Theorie sozialer Systeme. Cologne/Opladen: Westdeutscher Verlag. 3rd ed. (1972). With the title Soziologische Aufklärung 1. Reprint (2005). Wiesbaden: VS Verlag für Sozialwissenschaften.

(1970). Gesellschaft. In Luhmann, N., Soziologische Aufklärung (137-153).

Reprint (2005). Wiesbaden: VS Verlag für Sozialwissenschaften (173-193). (1971). Theorie der Gesellschaft oder Sozialtechnologie-Was leistet die Systemforschung? Frankfurt: Suhrkamp (together with Jürgen Habermas).

(1971). Politische Planung: Aufsätze zur Soziologie von Politik und Verwaltung.

Opladen: Westdeutscher Verlag.

(1972). Religion-System und Sozialisation. Darmstadt/Neuwied: Luchterhand (together with Karl-Wilhelm Dahm \& Dieter Stoodt).

(1973). Personal im öffentlichen Dienst: Eintritt und Karrieren. Baden-Baden:

Nomos (together with Renate Mayntz).

(1974). Rechtssystem und Rechtsdogmatik. Stuttgart: Kohlhammer.

(1975). Konfliktpotentiale in sozialen Systemen. In Landeszentrale für politische Bildung des Landes Nordrhein-Westfalen (Ed.), Der Mensch in den Konfliktfeldern der Gegenwart. Cologne: Verlag Wissenschaft \& Politik (67-74).

(1975). Soziologische Aufklärung 2: Aufsätze zur Theorie der Gesellschaft. Opladen: Westdeutscher Verlag. Reprint (2005). Wiesbaden: VS Verlag für Sozialwissenschaften.

(1975). Über die Funktion der Negation in sinnkonstituierenden Systemen.

In Weinrich, H. (Ed.), Positionen der Negativität. Munich: Fink (201218). Reprint (1981). In Luhmann, N., Soziologische Aufklärung 3 (35- 49). Reprint (2005). Wiesbaden: VS Verlag für Sozialwissenschaft (41-57).

(1977). Funktion der Religion. Frankfurt: Suhrkamp. Engl. transl. of pp. 72-181 (1984). Religious Dogmatics and the Evolution of Societies. New York/Toronto: Edwin Mellen Press. 
(1977). Interpenetration. Zum Verhältnis personaler und sozialer Systeme. In Zeitschrift für Soziologie 6, 62-76. Reprint (1981). In Luhmann, N., Soziologische Aufklärung 3 (151-169). Reprint (2005). Wiesbaden: VS Verlag für Sozialwissenschaft (172-192).

(1978). Interpenetration bei Parsons. In Zeitschrift für Soziologie 7, 299-302. (1979). Schematismen der Interaktion. In Kölner Zeitschrift für Soziologie und Sozialpsychologie 31 (237-255). Reprint (1981). In Luhmann, N., Soziologische Aufklärung 3. Soziales System, Gesellschaft, Organisation. Opladen: Westdeutscher Verlag, 1981 (81-100). Reprint (2005) Wiesbaden: VS Verlag für Sozialwissenschaft (93-114).

(1980). Gesellschaftsstruktur und Semantik: Studien zur Wissenssoziologie der modernen Gesellschaft I. Frankfurt: Suhrkamp.

(1980). Temporalstrukturen des Handlungssystems. Zum Zusammenhang von Handlungs- und Systemtheorie. In Schluchter, W. (Ed.), Verhalten, Handeln und System. Talcott Parsons' Beitrag zur Entwicklung der Sozialwissenschaften, Frankfurt a. M.: Suhrkamp, 32-67. Reprint (1981). In Luhmann, N., Soziologische Aufklärung 3 (126-150). Reprint (2005). Wiesbaden: VS Verlag für Sozialwissenschaft (143-171).

(1981). Gesellschaftsstruktur und Semantik: Studien zur Wissenssoziologie der modernen Gesellschaft II. Frankfurt: Suhrkamp.

(1981). Ausdifferenzierung des Rechts: Beiträge zur Rechtssoziologie und Rechtstheorie. Frankfurt, Suhrkamp.

(1981). Soziologische Aufklärung 3: Soziales System, Gesellschaft, Organisation. Opladen: Westdeutscher Verlag. Reprint (2005). Wiesbaden: VS Verlag für Sozialwissenschaft.

(1982). Zwischen Technologie und Selbstreferenz. Fragen an die Pädagogik. Frankfurt: Suhrkamp (together with Karl Eberhard Schorr, Eds.).

(1983). Medizin und Gesellschaftstheorie. I: Medizin, Mensch, Gesellschaft 8, 168-175.

(1983). Anspruchsinflation im Krankheitssystem. Eine Stellungnahme aus gesellschaftstheoretischer Sicht. In: Herder-Dorneich, P., \& Schuller, A. (Eds.), Die Anspruchsspirale. Schicksal oder Systemdefekt? 3. Kölner Kolloquium. Stuttgart/Berlin/Köln/Mainz: Kohlhammer (28-49).

(1985). Die Autopoiesis des Bewußtseins. In Soziale Welt 36, 402-446. Reprint (1987). In Hahn, A., \& Kapp V. (Eds.), Selbstthematisierung und Selbstzeugnis. Bekenntnis und Geständnis. Frankfurt: Suhrkamp (25-94). Reprint (1995). In Luhmann, N., Soziologische Aufklärung 6 (55-112). Reprint (2005). Wiesbaden: VS Verlag für Sozialwissenschaften (55-108). 
(1985). Von der allmählichen Auszehrung der Werte. Sind die Zeiten gesellschaftlicher Utopien für immer vorbei? In Voswinkel, G., \& von Baudissin, W. (Ed.), Zu neuen Ufern oder Aufbruch in die Sackgasse? Zum Problem des Fortschritts in unserer Zeit. Minden: Stadt Minden (69-76). (1986). Die soziologische Beobachtung des Rechts. Frankfurt: Metzner. (1986). Die Codierung des Rechtssystems. In Rechtstheorie 17, 171-203. (1986). Zwischen Intransparenz und Verstehen. Fragen an die Pädagogik. Frankfurt: Suhrkamp (together with Karl Eberhard Schorr, Eds.).(1986). „Distinctions directrices“: Über Codierung von Semantiken und Systemen. In Neidhardt, F., Lepsius, M. R., Weiß, J. (Eds.), Kultur und Gesellschaft. Special Issue n. 27 of Kölner Zeitschrift für Soziologie und Sozialpsychologie, 145-161. Reprint (1987). In Luhmann, N., Soziologische Aufklärung 4 (13-31). Westdeutscher Verlag: Opladen.

(1986). Codierung und Programmierung. Bildung und Selektion im Erziehungssystem. In Tenorth, H.-E. (Ed.), Allgemeine Bildung: Analysen zu ihrer Wirklichkeit, Versuche über ihre Zukunft. Weinheim/München: Juventa (154-182). Reprint (1987). In Luhmann, N., Soziologische Aufklärung 4 (182-201). Reprint (2005). Wiesbaden: VS Verlag für Sozialwissenschaften (193-213). Reprint (2004). In Luhmann,N., Schriften zur Pädagogik. Ed. By Lenzen, D. Frankfurt: Suhrkamp (23-47).

(1986). Die Zukunft der Demokratie. In Akademie der Künste Berlin (West) (Ed.), Der Traum der Vernunft. Vom Elend der Aufklärung. Eine Veranstaltungsreihe der Akademie der Künste Berlin. Zweite Folge. Darmstadt/Neuwied: Luchterhand (207-217).

(1988). Selbstreferentielle Systeme. In Simon, F. B. (Ed.), Lebende Systeme:

Wirklichkeitskonstruktionen in der systemischen Therapie (47-53). Berlin. (1988). Sozialsystem Familie. In System Familie 1, 75-91. Reprint (enlarged: 1990). In Luhmann, N., Soziologische Aufklärung 5 (196-217). Reprint (2005). Wiesbaden: VS Verlag für Sozialwissenschaften (189-209).

(1987). Soziologische Aufklärung 4: Beiträge zur funktionalen Differenzierung der Gesellschaft. Opladen: Westdeutscher Verlag. Reprint (2005). Wiesbaden: VS Verlag für Sozialwissenschaften.

(1987). Archimedes und wir: Interviews. Ed. by Baecker, D., \& Stanitzek, G.

Berlin: Merve Verlag.

(1987). Autopoiesis als soziologischer Begriff. In: Haferkamp, H., \& Schmid,

M. (Eds.), Sinn, Kommunikation und soziale Differenzierung. Beiträge zu Luhmanns Theorie sozialer Systeme. Frankfurt: Suhrkamp (307-324). (1988). Die Wirtschaft der Gesellschaft. Frankfurt: Suhrkamp. 
(1988). Erkenntnis als Konstruktion. Bern: Benteli.

(1989). Gesellschaftsstruktur und Semantik: Studien zur Wissenssoziologie der modernen Gesellschaft III. Frankfurt: Suhrkamp.

(1989). Individuum, Individualität, Individualismus. In Gesellschaftsstruktur und Semantik. Studien zur Wissenssoziologie der modernen Gesellschaft III (149-258).

(1989). Reden und Schweigen. Frankfurt: Suhrkamp (together with Peter Fuchs).

(1989). Geheimnis, Zeit und Ewigkeit. In Luhmann, N., \& Fuchs, P., Reden und Schweigen (101-137).

(1989). Gleichzeitigkeit und Synchronisation. Grund- und Integrativwissenschaftliche Fakultät, Wien: Institut für Soziologie. Reprint (1990). In Luhmann, N., Soziologische Aufklärung 5 (95-130).

(1990). Beobachter: Konvergenz der Erkenntnistheorien? Munich: Fink (together with Humberto Maturana, Mikio Namiki, Volker Redder \& Francisco Varela).

(1990). Soziologische Aufklärung 5: Konstruktivistische Perspektiven. Opladen: Westdeutscher Verlag. Reprint (2005). Wiesbaden: VS Verlag für Sozialwissenschaften.

(1990). Die Wissenschaft der Gesellschaft. Frankfurt: Suhrkamp. Engl. transl. of chapter 10 („Die Modernität der Wissenschaft“) (1994). New German Critique, 61, 9-23. Reprint (2002). In Theories of Distinction: Rediscriptions of the Descriptions of Modernity (61-75).

(1990). Zwischen Anfang und Ende. Fragen an die Pädagogik. Frankfurt: Suhrkamp (together with Karl Eberhard Schorr, Eds.).(1990). Unbeobachtbare Welt. Über Kunst und Architektur. Bielefeld: Haux (together with Frederick D. Bunsen \& Dirk Baecker).

(1990). Weltkunst. In Luhmann, N., et al. Unbeobachtbare Welt (7-45). Reprint (2008). In Luhmann, N., Schriften zu Kunst und Literatur (189-245).

(1990). Risiko und Gefahr. In Luhmann, N., Soziologische Aufklärung 5. Konstruktivistische Perspektiven. Opladen: Westdeutscher Verlag (131-169). Reprint (2005). Wiesbaden: VS Verlag für Sozialwissenschaften, (126-162). (1990). Glück und Unglück der Kommunikation in Familien. Zur Genese von Pathologien. In Luhmann, N., Soziologische Aufklärung 5 (218-227). Reprint (revised: 1992). In Königswieser, R., Lutz Ch. (Ed.), Das systemisch evolutionäre Management. Der neue Horizont für Unternehmer. Wien: Orac (298-306).

(1990). Der medizinische Code. In Soziologische Aufklärung 5 (183-195). 
(1991). Die Form „Person“. In Soziale Welt 42, 166-175. Reprint (1995). In Luhmann, N., Soziologische Aufklärung 6 (142-154). Reprint (2005). Wiesbaden: VS Verlag für Sozialwissenschaften (137-148).

(1991). Selbstorganisation und Information im politischen System. In Niedersen, U., \& Pohlmann, L. (Ed.), Der Mensch in Ordnung und Chaos, Selbstorganisation. Berlin: Duncker \& Humblot (11-26).

(1992). Teoria della società. Milano: Franco Angeli (together with Raffaele De Giorgi).

(1992). Universität als Milieu. Ed. by Kieserling, A. Bielefeld: Haux.

(1992). Zwischen Absicht und Person. Fragen an die Pädagogik. Frankfurt: Suhrkamp (together with Karl Eberhard Schorr, Eds.).

(1992). System und Absicht der Erziehung. In Luhmann, N., \& Schorr K.-E. (Eds.), Zwischen Absicht und Person. Fragen an die Pädagogik. Frankfurt: Suhrkamp, 102-124.

(1993). Das Paradox der Menschenrechte und drei Formen seiner Entfaltung. In Aarnio, A., Paulson, S.L., Weinberger, O., von Wright, G.H., \& Wyduckel D. (Eds.), Rechtsnorm und Rechtswirklichkeit. Festschrift für Werner Krawietz zum 60. Geburtstag. Berlin: Duncker und Humblot (539546). Reprint (1995). In Luhmann, N., Soziologische Aufklärung 6 (229236).

(1994). Inklusion und Exklusion. In Berding, H. (Ed.), Nationales Bewußtsein und kollektive Identität. Frankfurt: Suhrkamp (15-45). Reprint in (1995). Luhmann, N., Soziologische Aufklärung 6 (237-264).

(1995). Soziologische Aufklärung 6: Die Soziologie und der Mensch. Opladen:

Westdeutscher Verlag. Reprint (2005). Wiesbaden: VS Verlag für Sozialwissenschaften.

(1995). Gesellschaftsstruktur und Semantik: Studien zur Wissenssoziologie der modernen Gesellschaft IV. Frankfurt: Suhrkamp.

(1996). Protest: Systemtheorie und soziale Bewegungen. Ed. and introduced by Hellmann, K.-U. Frankfurt: Suhrkamp.

(1996). Zwischen System und Umwelt. Fragen an die Pädagogik. Frankfurt:

Suhrkamp (together with Karl Eberhard Schorr, Eds.).

(1996). Die Sinnform Religion. In Soziale Systeme 2, 3-33.

(2000). Organisation und Entscheidung. Opladen: Westdeutscher Verlag.

(2000). Die Politik der Gesellschaft. Ed. by Kieserling, A. Frankfurt:

Suhrkamp.

(2002). Das Erziehungssystem der Gesellschaft. Ed. by Lenzen, D. Frankfurt: Suhrkamp. 
(2004). Schriften zur Pädagogik. Ed. and introduced by Lenzen, D. Frankfurt: Suhrkamp.

(2005). Einführung in die Theorie der Gesellschaft. Ed. by Baecker, D. Heidelberg: Carl-Auer-Systeme Verlag.

(2008). Ideenevolution. Ed. by Kieserling, A. Frankfurt: Suhrkamp.

(2008). Die Moral der Gesellschaft. Ed. by Horster, D. Frankfurt: Suhrkamp.

(2008). Schriften zu Kunst und Literatur. Ed. by Werber, N. Frankfurt:

Suhrkamp.

(2013). Politische Soziologie. Frankfurt: Suhrkamp. Ed. by Kieserling, A. Reprint (2015).

(2013). Kontingenz und Recht. Rechtstheorie im interdisziplinären Zusammenhang. Ed. by Schmidt, J.F.K.. Berlin: Suhrkamp.

(2013). Macht im System. Ed. by Kieserling, A. Berlin: Suhrkamp.

(2014). Klaus Dammann (ed.), Wie halten Sie's mit Außerirdischen, Herr Luh-

mann? Nicht unmerkwürdige Gespräche mit Niklas Luhmann. Berlin:

Kulturverlag Kadmos.

(2016). Der neue Chef. Ed. by and with an afterword of Kaube, J. Berlin: Suhrkamp.

(2017). Die Kontrolle von Intransparenz. Ed. by and with an afterword of Baecker, D. Berlin: Suhrkamp.

(2017). Systemtheorie der Gesellschaft. Ed. by Schmidt, J.F.K., \& Kieserling,

A. Berlin: Suhrkamp.

(2018). Schriften zur Organisation 1. Die Wirklichkeit der Organisation. Ed. by Lukas, E. \& Tacke, V. Wiesbaden: Springer.

(2019). Schriften zur Organisation 2. Theorie organisierter Sozialsysteme. Ed.

by Lukas, E. \& Tacke, V. Wiesbaden: Springer.

(2019). Schriften zur Organisation 3. Gesellschaftliche Differenzierung. Ed. by Lukas, E. \& Tacke, V. Wiesbaden: Springer.

(2020): Schriften zur Organisation 4. Reform und Beratung. Ed. by Lukas, E. \& Tacke, V. Wiesbaden: Springer. 


\section{Bielefeld University Press}

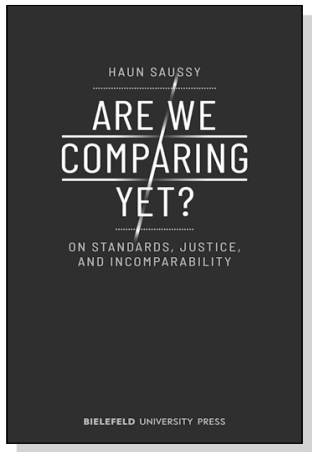

Haun Saussy

Are We Comparing Yet?

On Standards, Justice, and Incomparability

2019, 112 p., pb.

19,99€ (DE), 978-3-8376-4977-2

E-Book: available as free open access publication

PDF: ISBN 978-3-8394-4977-6

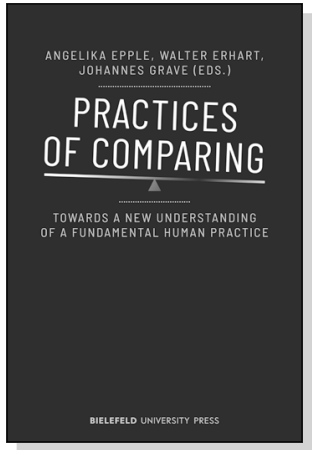

Angelika Epple, Walter Erhart, Johannes Grave (eds.)

\section{Practices of Comparing}

Towards a New Understanding of a Fundamental Human

Practice

June 2020, 406 p., pb., col. ill.

39,00 € (DE), 978-3-8376-5166-9

E-Book: available as free open access publication

PDF: ISBN 978-3-8394-5166-3

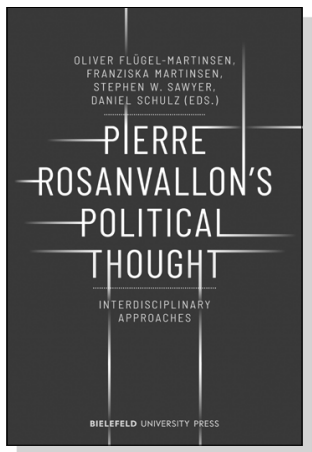

Oliver Flügel-Martinsen, Franziska Martinsen,

Stephen W. Sawyer, Daniel Schulz (eds.)

Pierre Rosanvallon's Political Thought

Interdisciplinary Approaches

2018, 248 p., pb.

39,99€ (DE), 978-3-8376-4652-8

E-Book: available as free open access publication

PDF: ISBN 978-3-8394-4652-2 
